\title{
Service-Learning as a Catalyst for Community Change: An Empirical Examination Measuring the Benefits of a Life Skills Curriculum in Local At-Risk High Schools
}

\author{
Roxanne Helm-Stevens ${ }^{1}$, Mark Dickerson ${ }^{1} \&$ Randy Fall ${ }^{2}$ \\ ${ }^{1}$ School of Business and Management, Azusa Pacific University, Azusa, CA, United States \\ ${ }^{2}$ Department of Educational Leadership, Azusa Pacific University, Azusa, CA, United States \\ Correspondence: Roxanne Helm-Stevens, School of Business and Management, Azusa Pacific University, 901 East \\ Alosta Avenue, CA, United States, 91702. Tel: 1-626-815-6000. E-mail: rhelmstevens@apu.edu
}

Received: January 20, 2019

Accepted: February 8, 2019

Online Published: February 14, 2019

doi:10.5430/bmr.v8n1p22

URL: https://doi.org/10.5430/bmr.v8n1p22

\begin{abstract}
This research attempts to measure the impact of service-learning on community recipients - at-risk high school students in urban Southern California. The service-learning project, an integrative, six-week assignment, involves upper-division business majors delivering the Options: Business Education and Life Skills curriculum to at-risk students in two local alternative education high schools. In addition to delivering business education and life skills, a critical design component of the curriculum is the opportunity for college students to be role models and provide mentoring guidance to at-risk high school students. This study used surveys to gather data on student perceptions of four constructs: (1) strengths and values, (2) school and work-related skills, (3) business etiquette and resume building, and (4) future life and career planning. Pre-tests and post-tests were administered to gauge differences in perception during the six-week service-learning project. Results indicated positive effects of the service-learning curriculum overall. Further, the data revealed statistically significant results with particularly noteworthy outcomes in the planning for the future and preparing for the world of work responses.
\end{abstract}

Keywords: service-learning, community impact, at-risk high school students

\section{Introduction}

For many higher-education institutions, service-learning has been used as an integrative approach to learning; it is a practice which combines hands-on application of course material with pertinent service to the community. According to Honnet and Poulsen (1989), "[s]ervice, combined with learning, adds value to each and transforms both." The field of service-learning has been extensively researched, particularly in the area of impact on the participating students. Previous research has documented that service-learning has both a positive (Batchelder \& Root, 1994; Eyler, Root \& Giles, 1998; Osborne, Hammerich \& Hensley, 1998) and formative (Boss, 1994; Gorman, 1994) impact on university students. One particular benefit of service-learning is the increase in social responsibility of the student (Eyler, Giles, \& Braxton, 1997; Kendrick, 1996; Dharamsi et al., 2010). Research has also shown that service-learning furthers students' personal and social development and promotes academic skills and knowledge in the subjects they study (Astin \& Sax, 1998; Simons \& Cleary, 2006).

While there is a vast body of research on the positive impact of service-learning on university students, in comparison, little has been said about its impact on the community, including P-12 student participants. A study of the historical and philosophical review of service learning (see, e.g., Beatty, 2010) suggests that early practitioners of service-learning needed to defend it as an effective pedagogy as well as respond to changing social views of the purpose of higher education and therefore focused their research on the benefits of the model for college students.

More recently, researchers have become curious about the sustainability of service learning relationships between community-based organizations and institutions of higher education (Driscoll, Holland, Gelmon \& Kerrigan 1996; Gray, et al., 1998), causing them to focus on the benefits to all parties. Current research in this area has focused on the usefulness of service-learning to the community partner (Cohen \& Kinsey, 1994; Bringle \& Kremer, 1993; Gelmon, Holland \& Shinnamon, 1998; Gray et al., 1998; Nigro \& Wortham, 1998) and developing models to measure the impact of service-learning on the community (Driscoll, Holland, Gelmon, \& Kerrigan, 1996). 


\section{Prior Research}

While research into the benefits of service learning projects for college students is abundant (see, e.g., Astin \& Astin, 2000; Eyler \& Giles, 1999; Eyler, Giles, \& Braxton, 1997; Kuh, 2008; Moely, McFarland, Miron, Mercer \& Ilustre, 2002; Pascarella \& Terenzini, 2005), researchers have only begun exploring the impact of such projects on the participating community organizations and their clients during the past two decades (Cruz \& Giles, 2000; Tryon \& Stoecker, 2009). In their survey of empirical research on service learning, Eyler, Giles, and Gray (1999) reported only eight studies that investigated community impacts in service learning. Subsequent research has largely focused on satisfaction with the service learning program (Ferrari \& Worrall, 2000; Gelmon, 2003; Schachter \& Schwartz, 2009), building capacity of the community-based organizations (e.g., strengthening networks, improving fund-raising; Budhai, 2013; Carpenter \& Krist, 2011; Geller, Zuckerman \& Seidel, 2016; Olberding \& Hacker, 2016), strengthening town-gown relationships (Sandy \& Holland, 2006), utilizing free labor and knowledge of college students and other university resources (Budhai, 2013; Carpenter \& Krist, 2011; Edwards, Mooney \& Heald, 2001; Olberding \& Hacker, 2016; Worrall, 2007), and improved client service (Geller, Zuckerman \& Seidel, 2016; Gray, et al., 2000).

According to Tinkler, Tinkler, Hausman, and Strouse (2014), when the community partner's perspective is examined, it is generally with a focus on "(a) the nature of the partnership, often with a focus on the pragmatics needed to guide effective practice, including the need for "more coordination and communication" (Vernon \& Ward, 1999, p. 32 ); or (b) the benefit to the community partner, including a correlation between agency voice and benefits (Gelmon et al., 1998; Miron \& Moely, 2006)" (p. 138).

Prominent research barriers in examining the impact of service-learning on the community stems from data collection issues. As Cruz and Giles (2000) note: "because communities are complex constructs, it is impossible to control for all of the variables that can confound a research study" (p.29).

The few studies that have examined community benefits attempt to offer insight by utilizing data obtained from community organizations, not the community itself (Vernon \& Ward, 1999; Ferrari \& Worrall, 2000; Bushouse, 2005; Miron \& Moely, 2006; Sandy \& Holland, 2006; Worrall, 2007; Helm-Stevens, Fall, Havens, Garcia \& Polvi, 2014). Due to these various challenges, the available research often results in equivocal qualitative findings, thus necessitating a literary expansion in quantitative research on the community impact of service-learning.

The most thorough empirical research uncovered regarding this question was conducted by Schmidt and Rooby (2002). Their study of 260 elementary age children who participated in a tutoring program addressed how children and their teachers perceived the value of the tutoring, whether the children made measurable academic progress as determined via their SAT/9 Normal Curve Equivalent scores, and whether differences in tutor characteristics (attribution of causality of child's problems; efficacy of tutoring; intention for civic action; social justice attitude; diversity attitude; and similarity between tutor and child) are correlated to the other two questions. The study used a control group of 256 other children; however, the students assigned to each group were not chosen at random. The authors concluded that the tutored children had higher one-year gains in math and spelling and tutor similarity to the children correlated to stronger reading gains.

Also, in a large-scale evaluation of the Learn and Serve America, Higher Education (LSAHE) program RAND gathered data from 725 community-based organizations that participated in service learning programs supported by LSAHE as well as 597 CBOs in a control group. Gray, et al. (2000), summarized findings from the study, reporting that LSAHE students were relatively effective in teaching public school students' methods of conflict resolution and improving student achievement, as well as working with adults to improve literacy, job skills and parenting skills. Notwithstanding these two studies, there exists a notable pattern of inattention to the impact of service-learning on community recipients.

\section{Conceptual Framework}

This study is founded on a framework of Vygotskian constructivism, which emphasizes sociocultural interactions as central to the process of learning and development. We expected that the university students, closer in age and more aware of current cultural phenomena, could be more successful in connecting the high school students to the curriculum than adult teachers. Vygotsky also focused on knowledge as constructed by the individual, rather than as imparted by others. The role of a teacher in Vygotskian teaching, then, is to guide students toward learning, and to create situations in which students can discover understandings for themselves. This was, indeed how the university students brought the curriculum to the high school students. They rarely lectured or used worksheets or handouts, instead creating novel experiences for students to discover their own needs and desires related to careers. 


\section{Background}

Since 2001, students enrolled in the university's Organizational and Administrative Behavior class have been participating in service-learning projects as a part of their coursework. This required, upper-level management class is designed as a hybrid class, allowing students to attend class lectures as well as participate off-site for an intensive, off-site service-learning project. The service-learning project, an integrative, six-week assignment, requires upper-division business majors to plan and deliver business education and life skills curriculum to at-risk students in local alternative-education high schools. In groups of five to seven, university students are assigned a classroom where they teach one-hour business education and life skills lessons once a week for six consecutive weeks.

\section{Curriculum}

From 2001 to 2008, the curriculum taught by the university students was from Junior Achievement, a program used by a number of schools that operated in elementary, middle and high schools. However, the Junior Achievement curriculum became cost prohibitive in 2009. In response, the professor and several graduate assistants developed a new curriculum, Options: Business Education and Life Skills, targeted at non-traditional high school students.

Designed to provide both academic and life skills support to under-served, at-risk high school students, the Options: Business Education and Life Skills curriculum is based on two core pillars: education and mentorship. Intended to provide opportunities for mentorship, the curriculum is embedded with activities, exercises, and discussions.

\section{Research Design}

\subsection{Participants}

Two alternative high schools participated in the research, represented as British High School (5 classrooms) and French High School (6 classrooms). Both British and French are fully accredited California Model Continuation Education High Schools. Although some students are placed at these schools for disciplinary reasons, most are placed because they are behind in credits and are therefore not on track to graduate on time. Many of these students need individualized curriculum, instruction, or guidance and specialized attention within an alternative educational environment.

\subsection{British High School}

British High School is part of the Delta Unified School District. Of the 295 students enrolled at British High School, approximately $91 \%$ are Hispanic, 5\% are white, $2 \%$ are African American, and 1\% are Asian. There are two American Indian students and one student classified as two or more races. British High School has nineteen full-time teachers, with a student/teacher ratio of 16 to 1 . Student enrollment by grade level is as follows: 55\%, of the student population are in the $12^{\text {th }}$ grade, $44 \%$, are in the $11^{\text {th }}$ grade, and only $.7 \%$, of the 296 students are in the $10^{\text {th }}$ grade.

\subsection{French High School}

Part of the Alpha Unified School District, French High School has 89 students enrolled, 36\% are Hispanic, 54\% are white, $5.6 \%$, are Asian, and 4.4\%, are biracial or self-identified as other. There are eight full-time teachers at French High School with a student/teacher ratio of 11 to 1 . Student enrollment by grade level is as follows: $58 \%$ of the school student population are in the $12^{\text {th }}$ grade, $28 \%$, are in the $11^{\text {th }}$ grade, and $13 \%$ are in the $10^{\text {th }}$ grade.

\subsection{Sample}

The sample included 154 participants. Participants ranged in age from 15 to 19 , with an average age of 16.9. Participants were all in $10^{\text {th }}, 11^{\text {th }}$, or $12^{\text {th }}$ grade, with an average grade of 11.44. The collected sample was 65.5 percent male, and 34.5 percent female. Ethnicities as reported by participants were 62.1 percent Hispanic, 16.6 percent white, 13.7 percent Asian, and 1.4 percent Black.

\subsection{Instrument}

This research study used a Likert-scale survey instrument in the form of a 6-point questionnaire with 28 predetermined questions. Developed by Rensis Likert in 1932, the 6-point ordinal scale survey asked respondents to rate the degree to which they agreed or disagreed with statements. A study by Chomeya (2010) concluded that "Likert's scale 6 points tend to give the discrimination and reliability values which are higher than the Likert's scale 5 point" and that researchers looking to "reduce the deviation to be the least or reduce the risks which might happen from the deviation of personal decision making, should chose the Likert's scale 6 points instead of Likert's scale 5 points" (p. 402). This numerical instrumentation allowed for tabulation; however, responses could not be rated or ranked. 
Pre-test surveys were administered in participating continuation education high school classrooms with permission of the schools. Post-test surveys were administered in those same classrooms after the service-learning project concluded. Post-test surveys were distributed and gathered by teachers and later collected by the research team.

\section{Results}

Visual inspection of the means and frequencies for the questions reveal remarkably positive responses from students in both the pre-test and the post-test. While Likert-scale responses are ordinal data rather than interval or ratio, the use of means and standard deviations to describe Likert-scale responses has become common, and has some psychometric support (e.g., Sullivan \& Artino, 2013). Item means ranged from 3.77 to 5.33 (on a 6-point Likert scale) on the pre-test, and 3.95 to 5.43 on the post-test. Standard deviations ranged from 1.06 to 1.77. The means and standard deviations demonstrate a relatively narrow range of responses to the items, with predominantly positive responses. This limited range of responses on the pre-test likely reduced the likelihood of finding statistically significant differences between pre-test and post-test scores.

Remarkably, all of the means on the post-test were higher than the corresponding means on the pre-test, showing a general positive effect of the service-learning project. Analyzed individually using independent samples t-tests, five items showed statistically significant improvements from pre-test to post-test, see Table 1.

Table 1. Questions with statistically significant differences from pre-test to post-test

\begin{tabular}{lllll}
\hline Question & Mean difference & $\mathrm{t}$ & $\mathrm{df}$ & $\mathrm{p}$ \\
\hline 1. I feel that I have an understanding of appropriate & .40 & 3.15 & 275 & .002 \\
$\quad$ business behavior & & & & \\
9. I feel confident that I could make my own resume & .46 & 2.82 & 275 & .005 \\
10. I often plan for the future & .45 & 2.74 & 275 & .005 \\
11. I have a plan of where I want to be 3-5 years from now & .41 & 2.25 & 275 & .025 \\
21. I know how to write a cover letter & .39 & 2.17 & 275 & .032
\end{tabular}

We next computed scales combining similar items, resulting in six scales: self-knowledge, work, goals, skills, resources and attitude. While trends were clearly toward improvement in all scales, none of the scales showed statistically significant differences between pre-test and post-test. Pre-test and post-test means and standard deviations are presented in Table 2.

Table 2. Pre-test and post-test scores by scale

\begin{tabular}{lcccc}
\hline Constructs & \multicolumn{2}{c}{ Pre-test } & \multicolumn{3}{c}{ Post-test } \\
\hline Mean & Self-knowledge & $\underline{\text { SD }}$ & $\underline{\text { Mean }}$ & $\underline{\text { SD }}$ \\
Work & 4.98 & $(.96)$ & 5.13 & $(.85)$ \\
Skills & $(.93)$ & 4.82 & $(.88)$ \\
Resources & 4.41 & $(.86)$ & 4.59 & $(.89)$ \\
Goals & 4.77 & $(.99)$ & 4.95 & $(.88)$ \\
Attitude & 4.74 & $(1.12)$ & 4.99 & $(.97)$ \\
& 5.18 & $(.89)$ & 5.33 & $(.70)$
\end{tabular}

When we compared results by gender, we found no significant differences by gender on the pre-test. On the post-test, independent samples t-tests did identify statistically significant differences between males and females on the scales of skills (Males $\mathrm{M}=4.63, \mathrm{SD}=.80$; Females $\mathrm{M}=4.55, \mathrm{SD}=1.03 ; \mathrm{t}(265)=5.50, \mathrm{p}=.02$ ) and attitude (Males $\mathrm{M}=5.19, \mathrm{SD}=.77$; Females $\mathrm{M}=5.59, \mathrm{SD}=; 51 \mathrm{t}(265)=5.31, \mathrm{p}=.02$ ). While both groups exhibited high scores on the post-test, females showed higher confidence in both skills and attitude than males.

\section{Discussion}

Our analysis of student responses to the surveys revealed an overall positive effect of the intervention, though with a few unexpected findings. The pre-test scores were remarkably high overall, showing that students generally held positive views of their skills and preparation for their work life after high school. This positive belief stands in contrast to well-established findings about outcomes for this at-risk population. We posit two hypotheses to explain this discrepancy- first, that students define success in the world of work somewhat differently than academics and 
researchers, with employment defined as a reasonable success. Second, students seem to trust that the preparation they have received in high school is appropriate and applicable to life after high school, perhaps trusting the educational system more than is warranted.

The intervention had specific effects in the areas of planning and work-readiness. These effects were expected, since these areas were the intentional focus of modules within the curriculum. Students generally self-identified one of three goals after high school, a job, further education, or the military. In the module on planning, students were led through activities in which they identified long term goals, and then structured short-term goals that could lead them toward their long-term goals. For example, a student with an interest in law enforcement would research the education and background needed, then write five short-term goals that they could accomplish while in high school that would move them closer to that long-term goal.

Students showed significant benefits of the intervention in specific skills required for job applications and the world of work. Post-test scores indicated that students had more confidence in their skills in writing resumes, writing cover letters, and appropriate business behavior. During class sessions, the high school students were guided in activities designed to identify work-related experiences (baby-sitting, lawn-care, etc.), then constructed draft resumes with the help of university students. High school students were also grouped in small groups to discuss and practice interview techniques.

The intervention also showed an impact on students' planning for the future. The module addressed how to apply for financial aid, the jobs that require training and jobs that require a college education. Many students did not consider college before their interaction with the university students, so the presence of the university students and the relationships between the two groups led a number of the high school students to begin to consider college education. It was common for the high school students to be surprised that their areas of interest required education. For example, several students identified hairdressing as a possible career, but were not aware of the need to complete additional hairdressing school and state licensure to pursue that career.

Following the work of Piaget, Vygotsky's Social Constructivists Theory of Learning (1978) posits social interaction plays a fundamental role in the progression of cognitive development. The university student worked on tasks cooperatively with the high school students, these shared social interactions may have served an instructional function.

\section{Implications}

The results of this study have some important implications for the planning and practice of service learning projects with university and high school students. Our project included university students who generally came from middle-class or upper middle-class homes working with student from working-class environments. Working with those demographics, our research establishes the importance of a holistic view of the future for the high school participants. It would be counterproductive and unrealistic to go to this group of students and say that all should go to college. Instead, we found that students were able to articulate goals that could lead to a wide range of options after school, including military service, trade school, employment, and community college, along with traditional college. Our high school students responded well to being asked about their goals and aspirations, rather than having goals and paths suggested for them.

\section{Limitations}

The challenges associated with quantifying the effects of the service-learning project in the community produced several data gathering constraints. A major limitation was the fluidity of the population. Due to a variety of factors, at-risk students attending alternative and continuing education schools have a tendency to relocate more often than students enrolled in traditional high schools. Since changes in student roster had the potential to create inconsistencies in data extraction, semester surveys are therefore exposed to a bias.

The inherent constraints of the continuing education system also posed several obstacles. Since these at-risk school sites typically do not give homework, the homework question is limited in its validity and thus can hinder the adequacy of the School and Work-Related Skills construct.

In addition to data gathering impediments, there were methodology limitations. First, simple random sampling was utilized as students were assigned to service-learning classes by the administration of the respective schools. Given that sampling was limited to schools in a small portion of Los Angeles County, the findings may not adequately represent the at-risk high school population. 
Lastly, possible variation in the delivery of lesson plans to high-school students has the potential to enhance or diminish engagement and participation. For example, it is likely that different groups structured classroom activities in ways that required students to become more involved. Different teaching styles and classroom activities could influence the students' level of participation and engagement and understanding of the lesson plan. Analyzing these differences may further our understanding of the high school students' participation and engagement with the curriculum and the university students.

\section{Future Research}

Several avenues for future research are suggested by our study. First, future research should examine whether this kind of curriculum can be duplicated with different populations, both university and high school populations. This study focused on urban communities and at-risk high school students in southern California. It would be helpful to know whether the impact we found on planning, education and public speaking could be reliably reproduced.

Second, we have noted that the university students developed much of their methods for implementing the curriculum by working in cooperative groups. An analysis of that group work could be very promising in identifying the forms of interaction and roles within the groups that lead to successful service learning curriculum delivery.

A third line of inquiry is how different curricula would change the identified impacts on at-risk high school students. For example, other life skills addressing physical and mental health (e.g., exercise, nutrition, stress reduction) could be added to the curriculum.

\section{Conclusion}

Due to its ground-breaking nature, this study's findings are admittedly limited in their ability to provide generalizations or serve as a comparison to similar studies. Yet, this research yielded positive and encouraging findings. The researchers feel this is a critical study since there is not sufficient literature detailing the effects of service-learning on community members. The literature review for this study revealed that the majority of the articles examining the impact on community were exploratory and qualitative in nature.

This study provided a brief look into the benefits of a semester long service-learning project to community recipients. More research needs to be conducted on the impact of service-learning on the community and the members of the community. Further studies may focus on whether the relationships found in this study within these contexts also hold true for other geographical areas or other contexts, such as, traditional students. Thus, future studies may examine the relationships between the variables under investigation in other educational settings.

\section{Acknowledgements}

This research was supported by Aaron Acosta, Shane Shannon, Kevin Stough, and Orlando Griego.

\section{Notes}

A copy of the survey may be obtained by contacting the corresponding author.

\section{References}

Astin, A. W., \& Sax, L. J. (1998). How undergraduates are affected by service participation. Journal of College Student Development, 39, 251-263.

Astin, A. W., \& Astin. H. S. (2000). Leadership reconsidered: Engaging higher education in social change. Battle Creek, MI: W. K. Kellogg Foundation.

Batchelder, T.H., and Root, S. (1994). Effects of an Undergraduate Program to Integrate Academic Learning and Service: Cognitive, Prosocial Cognitive, and Identity Outcomes. Journal of Adolescence, 17, 341-355. https://doi.org/10.1006/jado.1994.1031

Beatty, J. E. (2010). For which future? Exploring the implicit futures of service-learning. International Journal of Organizational Analysis, 18(2), 181-197. https://doi.org/10.1108/19348831011046254

Boss, J. A. (1994). The Effect of Community Service on the Moral Development of College Ethics Students. Journal of Moral Development, 23(2), 183-198. https://doi.org/10.1080/0305724940230206

Bringle, R. G., \& Hatcher, J. A. (2000). Institutionalization of Service-Learning in Higher Education. Journal of Higher Education, 71(3), 273-290. https://doi.org/10.2307/2649291 
Budhai, S. S. (2013). Two sides to every story: Exploring community partners' perspective of their service learning experiences. Community College Journal for Civic Commitment, 20 (https://www.mesacc.edu/community-civic-engagement/journals).

Bushouse, B. K. (2005). Community Nonprofit Organizations and Service-Learning: Resource Constraints to Building Partnerships with Universities. Michigan Journal of Community Service Learning, 12(1), 32-40.

Carpenter, H. L. \& Krist, P. (2011). Practice makes perfect: Impact and use of nonprofit master students' applied projects on nonprofit organizations in the San Diego region. Journal of Nonprofit Education and Leadership, $1(2), 61-77$.

Chomeya, R. (2010). Quality of Psychology Test Between Likert Scale 5 and 6 Points, Journal of Social Sciences, 6(3), 399-403. https://doi.org/10.3844/jssp.2010.399.403

Cohen, J. \& Kinsey, D. F., (1994). Doing Good and Scholarship: A Service-Learning Study. Journalism Educator, 48(4), 4-14. https://doi.org/10.1177/107769589304800402

Cruz, N. I., \& Giles, D. E. (2000). Where's the community in service-learning research. Michigan Journal of Community Service Learning, 7(1), 28-34.

Dharamsi, S., Espinoza, N., Cramer, C., Amin, M., Bainbridge, L., \& Poole, G. (2010). Nurturing social responsibility through community service-learning: Lessons learned from a pilot project. Medical Teacher, 32(11), 905-911. https://doi.org/10.3109/01421590903434169

Driscoll, A., Holland, B., Gelmon, S., \& Kerrigan, S. (1996). An Assessment Model for Service- Learning: Comprehensive Case Studies of Impact on Faculty, Students, Community, and Institutions. Michigan Journal of Community Service Learning, 3, 66-71.

Edwards, B., Mooney, L. \& Heald, C. (2001). Who is being served? The impact of student volunteering on local community organizations. Nonprofit and Voluntary Sector Quarterly, 30(3), 444-461. https://doi.org/10.1177/0899764001303003

Eyler, J., Giles Jr, D. E., \& Braxton, J. (1997). The impact of service-learning on college students. Michigan Journal of Community Service Learning, 4, 5-15.

Eyler, J. and D. E. Giles (1999). Where's the learning in service learning? San Francisco, John Wiley \& Sons.

Eyler, J. Giles, D., \& Gray, C. (1999). At a glance: What we know about the effects of service=learning on students, faculty, institutions, and communities, 1993-1999. University of Minnesota: National Service-Learning Clearinghouse (www.umn.edu/ serve).

Ferrari, J. R., \& Worrall, L. (2000). Assessments by community agencies: How "the other side" sees service-learning. Michigan Journal of Community Service Learning, 7(1), 35-40.

Geller, J. D., Zuckerman, N., \& Seidel, A. (2016). Service-learning as a catalyst for community development: How do community partners benefit from service-learning? Education and Urban Society, 48(2), 151-175. https://doi.org/10.1177/0013124513514773

Gelmon, S. B. (2003). Assessment as a means of building service-learning partnerships. In B. Jacoby and Associates (Eds.), Building partnerships for service-learning (pp. 42-64). San Francisco: John Wiley and Sons, Inc.

Gelmon, S. B., Holland, B. A., Seifer, S. D., Shinnamon, A. \& Connors, K. (1998). Community- university partnerships for mutual learning. Michigan Journal of Community Service Learning, 5(1), 97-107.

Gelmon, S. B., Holland, B. A., \& Shinnamon, A. F. (1998). Health Professions Schools in Service to the Nation: Final Evaluation Report. San Francisco, CA: Community Campus Partnerships for Health.

Gorman, M. (1994). Service Experience and the Moral Development of College Students. Religious Education, 89(3), 422-431. https://doi.org/10.1080/0034408940890308

Gray, M.J., Ondaatje, E. H., Fricker, R., Geschwind, S., Goldman, C. A., Kaganoff, T., Robyn, A., Sundt, M., Vogelgesang, L., \& Klein, S. P. (1998). Coupling Service and Learning in Higher Education: The Final Report of the Evaluation of the Learn and Serve America, Higher Education Program. The RAND Corporation.

Gray, M. J., Ondaatje, E. H., Fricker, Jr., R. D., \& Geschwind, S. A. (2000). Assessing service-learning: Results from a survey of "Learn and Serve America, Higher Education," Change, 32(2), 30-39. https://doi.org/10.1080/00091380009601721 
Helm-Stevens, R., Fall, R., Havens, C., Garcia, M., Polvi, L. (2014). The Impact Of Service-Learning Curriculum At A Local At-Risk High School: An Examination Of Preliminary Data, American Journal of Economics and Business Administration, 6(3), 122-132. https://doi.org/10.3844/ajebasp.2014.122.132

Honnet, E.P. \& Poulsen. (1989). Principles of good practice in combining service and learning (Wingspread Special Report) Racine Wisconsin: The Johnson Foundation.

Kendrick Jr, J. R. (1996). Outcomes of Service-Learning in an Introduction to Sociology Course. Michigan Journal of Community Service Learning, 3, 72-81.

Kuh, G. D. (2008). High-impact educational practices: What they are, who has access to them, and why they matter. Washington, D. C., Association of American Colleges and Universities.

Likert, R. (1932). A technique for the measurement of attitudes. Arch Psychology, 22(140), 55.

Miron, D., \& Moely, B. E. (2006). Community Agency Voice and Benefit in Service-Learning. Michigan Journal of Community Service Learning, 12(2), 27-37.

Moely, B. E., et al. (2002). Changes in college students' attitudes and intentions for civic involvement as a function of service-learning experience. Michigan Journal of Community Service Learning, 9(1), 18-26.

Nigro, G., \& Wortham, S. (1998). Service-learning through action research. In R. G. Bringle and D. K. Duffy (Eds.) Collaborating With the Community: Psychology and Service- Learning. Washington DC: American Association for Higher Education.

Olberding, J. C. \& Hacker, W. (2016). Does the "service" in service learning go beyond the academic session? Journal of Nonprofit Education and Leadership, 6(1), 25-46.

Osborne, R. E., Hammerich, S., \& Hensley, C. (1998). Student Effects of Service-Learning: Tracking Change Across a Semester. Michigan Journal of Community Service Learning, 5, 5-13.

Pascarella, E. T. and P. T. Terenzini (2005). How college affects students: A third decade of research. San Francisco, Jossey-Bass.

Sandy, M., \& Holland, B. A. (2006). Different worlds and common ground: Community partner perspectives on campus-community partnerships. Michigan Journal of Community Service Learning, 13(1), 30.

Schachter, D. R. \& Schwartz, D. (2009). The value of capstone projects on participating client agencies. Journal of Public Affairs Education, 15, 445-461. https://doi.org/10.1080/15236803.2009.12001571

Schmidt, A., \& Robby, M. A. (2002). What's the Value of Service-Learning to the Community? Michigan Journal of Community Service Learning, 9, 27-33.

Simons, L., \& Cleary, B. (2006). The influence of service learning on students' personal and social development. College Teaching, 54(4), 307-319. https://doi.org/10.3200/CTCH.54.4.307-319

Sullivan, G. M., \& Artino, A. R. (2013). Analyzing and interpreting data from likert-type scales. Journal of graduate medical education, 5(4), 541-552. https://doi.org/10.4300/JGME-5-4-18

Tinkler, A., Tinkler, B., Hausman, E., Strouse, G. (2014). Key elements of effective service-learning partnerships from the perspective of community partners. Partnerships: A Journal of Service-Learning \& Civic Engagement, $5(2), 137-152$.

Tryon, E. \& Stoecker, R. (2009). The unheard voices: Community organizations and service learning. Philadelphia, PA: Temple University Press.

Vernon, A., \& Ward, K. (1999). Campus and Community Partnerships: Assessing Impacts and Strengthening Connections. Michigan Journal of Community Service Learning, 6, 30-37.

Vygotsky, L. (1962). Thought and language. (E. Hanfmann \& G. Vakar, Eds.). Cambridge, MA: MIT University Press. http://dx.doi.org/10.1037/11193-000

Vygotskii, L.S. (1978). Mind in society: The development of higher mental processes. Cambridge, MA: Harvard University Press.

Worrall, L. (2007). Asking the community: A case study of community partner Perspectives. Michigan Journal of Community Service Learning, 14(1), 5-17. 